\title{
African Ethiopia and Byzantine imperial orthodoxy: Politically influenced self-definition of Christianity
}

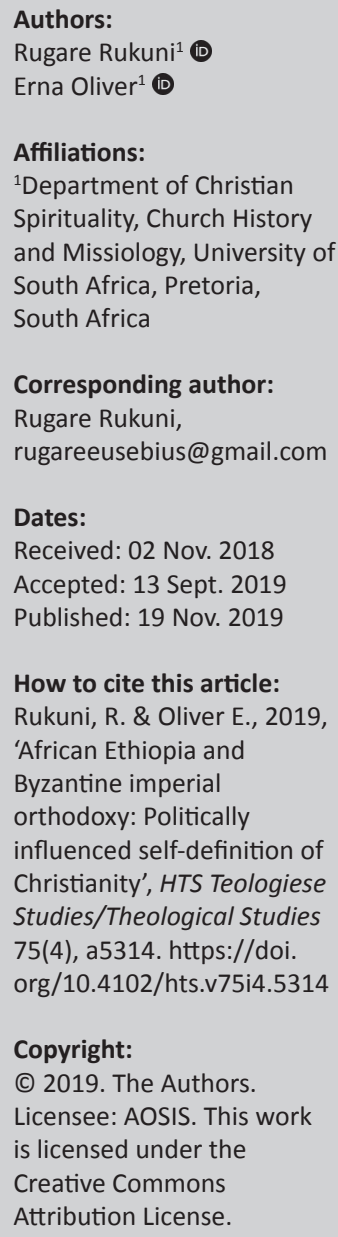

The ancient Ethiopian Christian empire was an emergent and notable power in Eastern Africa and influenced its surrounding regions. It was itself influenced both religiously and politically. The ancient Christian narrative of North Africa has been deduced against a Roman imperial background. Whilst the preceding is congruent with the historical political dynamics, a consideration of the autonomy and uniqueness of ancient African Christianity and its regional influence is also relevant. This implied a revisionist approach to literature which was achieved through document analysis. A review of the continual independent interaction of ancient African Christianity with Roman or Byzantine imperial orthodoxy reflected on the multifactorial self-definitive development within African Christianity. Against the background of ecclesiastical polities and socio-ethnical dynamics, the relationship of Africa or Ethiopia with Byzantine orthodoxy provides a strong argument for an organic African orthodoxy. The Constantinian era ushered a new phase of imperial orthodoxy and imperial-ecclesiastical ties that became formative for an imperial policy; these were definitive of Byzantine orthodoxy and were reflected in Roman and Vandal Africa and also in the Ethiopian Christian empire. This consequently characterised the orthodox Christianity post $325 \mathrm{CE} /$ Nicaea; introspection regarding the extent of its influence formed the basis of this study. A study of the Ethiopian empire in its immediate Judaic-Arabian environment enhances the understanding regarding the ethnically politically defined Christianity that characterised it. Correspondingly, the review of Ethiopian Christianity's interaction with Byzantine orthodoxy and definitive features of ancient North African Christianity helped clear the ground for an organic orthodoxy. An establishment regarding a cooperative Ethiopian-Byzantine geopolitical policy, as opposed to theological divergence, helped change the narrative of African orthodoxy.

Keywords: Church History; Ethiopian Christianity; Cultural-Definition; Byzantine Christianity; African Christianity; Imperial Christianity; Nicene Orthodoxy and Constantinianism.

\section{Introduction}

The 4th century witnessed the emergence of a religio-political outfit in the form of Constantinian Christianity (Leithart 2010:177). This was a factor that influenced the religious and political synergies. It is, however, not the conclusive narrative regarding Christianity at the turn of this era. Whilst the Constantinian imperial Christianity is notably significant for the creation of a regional influence and a culture of imperial clerical ties, this does not represent the entire Christian narrative (Alexander \& Smither 2015:169-170), more specifically with regard to North Africa and ultimately the imperial Kingdom of Ethiopia.

\section{The Constantinian era as a lens for reviewing the Christian empire of Ethiopia}

The Trinitarian debate that characterised the period from the 3rd to 4th century was a shaping factor for then emergent Christianity (Gray 2005). The solution of an ecumenical council of Nicaea and its aftermath was another important factor. The manner in which the council served as a religio-political solution was also notable. The manner in which the theological division was geographically delineable would be significant to ascertain the position taken by Ethiopia on this divide. It would also establish the independence or autonomy of the Ethiopian church in relation to Rome and later Byzantium.

\section{The relation regarding the political and ecclesiastical connection}

The interplay of ecclesiastical and imperial politics is intertwined with the Nicene narrative. For Eusebius, the church remained theosebes politeuma [a godly polity], governed by the episcopate and 
being out of the reach of the emperor (Leithart 2010:179). With time, Constantine's successors such as Constantius were engaged with the church into a greater extent. The latter styled himself as 'the bishop of bishops' episcopus episcoporum (Leithart 2010:180). Constantine also claimed to be a bishop for those without a bishop. This was a vague conceptualisation that raised the subject of Caesaropapism, either as a protector of Christendom or as an imperial missionary whom the emperor entrusted with an imperial Christian agenda (VC 4.24; Cameron \& Hall 1999:320; Rapp 2005:685; Schaff 1885b:826). The role of the episcopate was a notion pre-established by Cyprian in his Ecclesiastical Unity, it was inevitably apparent that the development of Christian ideology also meant the maturity of ecclesiastical politics (Unit Eccl 10-14; Schaff 1885b:744-746). Theophilus of Antioch was a significant corresponding episcopal figure in Eastern Christianity (Philostorgius EH 3.6; Amidon 2007:43).

\section{Independence from Byzantine Christendom}

Constantius II in accordance with his strained relationship with the Christian church as heir of the Constantinian political ecclesiastical link intended to ensure the dominance of Arian ideology as was acceptable to his policy.

The fallout of Athanasius with the emperor regarding his anti-Arian views that had won the day at Nicaea saw the rise of George of Cappadocia as the patriarch of Alexandria (Phillipson 2012:95). Constantinople could lay claim to the Episcopate of Alexandria, but the same could not be said of Aksum.

The evidence of adoption of Christianity by the Aksumite King Ezana finds confirmation in an attempt at meddling in the Christian affairs of the North African empire by the then emperor at Byzantium. To Athanasius' writings is attributed a letter by the emperor Constantius II addressed to Ezana and Sazana 356/357 CE (considered a joint ruler with Ezana). The subject of the letter was to realign episcopal loyalties regarding theological or Christological arguments. Since Frumentius, the then Patriarch, had been appointed by Athanasius who had been a proponent of anti-Arianism, the Byzantine emperor wanted him to be re-examined by his new Arian appointee, George of Cappadocia (Phillipson 2012:95). It appears there is no evidence of reciprocation regarding this letter at the Ethiopian court.

\section{Vandal Africa: Political and theological divergence Ethiopia in its African background}

Ethiopia has to be considered in its regional situation. The mutuality of geopolitical implications on itself and the other nations is an important factor. It appears African Christianity is characterised by dichotomy. These dichotomies although stemming from orthodoxy versus heresy intrinsically spilled over into politics. During the Constantinian era, there was a series of councils, notably one of them being the 314 CE Arles Synod (Frend 2012:522) (Optatus Don 1.11.4; Phillips 1917:23). In an attempt to resolving the Donatist schism, the council was determinant for military intervention against riots by the Donatist victims (Leithart 2010:160-161). The Donatist controversy transcended the clerical dispute and became definitive of any intransigent or divergent practice.

Whelan argues, as others have done, that this divide may be a consequence of the inclination of the primary authors involved (Whelan 2018:3). Given the emergence of Christianity in Ethiopia and its association with Byzantine Rome (Phillipson 2012:204), a look at the then 'Vandal Africa' would be relevant. Vandal Africa was the successor to Roman Africa; this was a consequence of the decline of Western Rome.

From the dominant source of this era (429 CE-484 CE), Victor of Vita, there was a depiction of the Vandal Arians versus the orthodox Nicene Christians. This is discussed in his treatise History of the Persecution of the African Province (Whelan 2018:9). Whelan despite his acknowledgement of the substantiality of Victor of Vita as a source for the period implies foundational deconstruction of the perceived divide between the Arian Vandals and Nicene Christianity. The non existence of a distinct divide is evidenced by the derivation from Constantius II's 359 CE twin councils of Remini and Seleucia in the $484 \mathrm{CE}$ post-council of Carthage edict by Huneric (HP 3.5, 3.12, Moorhead 1992:65, 67-68).

This perspective compositely builds the complex matrix of the ancient African theological and political definition in Christianity. For example, the divergence of Donatist, although it turned political, originally pertained to the views on baptism and authentic church leadership. Constantine's reversion to conciliar formulae for peace in this constituency of Christianity could have been a comprehension of the nonrelation between political and religious divergence.

The above observations can provide a good insight into deciphering the complex relationship between Byzantine Rome and Ethiopia. Geopolitical cooperation in the defence of persecuted Christians in Najran (Arabian Peninsula) (circa $525 \mathrm{CE}$ ) was not based on religious allegiance regarding the monophysite-diphysite arguments (Bowersock 2013:5, 75).

\section{Vandal Africa and Nicene orthodoxy}

The emperor Constantine introduced the notion of imperial Christianity (Barnes 2011:111). Imperial Christianity was an orthodoxy defined by the composite neo-imperial religious policy based on the active participation of the emperor (VC 4.24; Schaff 1885d:826). Historically, Constantine had definitive implications upon the geopolitical fabric. The unification of the empire and the founding of Nova Roma [New Rome] in the establishment of Byzantium, Constantinople as a Christian city had implications on the fabric of Christian orthodoxy. The division of the empire after Constantine and the decline of Western Rome implied revisions with regard to the newly established Christendom. 
The foundation of an orthodoxy that had the support of councils and imperial legislation as an enforcement to decrees had a geographical connotation. The benefactory tendencies of the emperor upon the episcopate, though entrenching an already existent system (Van Dam 2012:344), implied the rising eminence of the metropolitan clerics and ultimately their sees. Therefore, it can be deduced that Rome and later Byzantine would emerge as an arbiter of orthodoxy. The political changes in North Africa when Vandal Geiseric took over in $428 \mathrm{CE}$ would therefore imply a divergence from the established Roman orthodoxy.

Correspondingly, the accounts of Augustine and Victor portray the emergence of the Hasding Vandal dynasty as entry into a phase of persecution for those in conformity with Nicene orthodoxy (Fournier 2008, 2013). Whelan argues that there was a misguided commentary by Victor of Vita given a revision of the actions of the Vandals with regard to Christianity and the continued independence of the North African 'Arian' clerics (cf. Whelan 2018).

\section{Homousian versus Homoian}

Whelan underscores the proximity of the resolution proffered by Huneric - after the 484 CE Carthage council - to the $359 \mathrm{CE}$ Rimini and Seleucia councils of Constantius II as evidence for the clarity of non-Nicene orArian Christianity (Whelan 2018:12). The twin councils reverted to the word 'like' (homoios [Greek] and similis [Latin]), thereby disposing the lingua franca that had been conceived at Nicaea (Barnes 1993:144-151).

In Constantinian manner, the Hasding Vandal dynasty dabbled in ecclesiastical issues (Whelan 2018:15).

Amidst the theological diversity, the monarchy took the side of Homoian or semi-Arian Christians. The hostile measures inclusive of the exile of bishops - against the African Nicene party could be delimited geographically as it seemed to have been in the main province of Vandal Proconsularis (Conant 2012:161-170). Huneric engaged in a coercion crusade for conformity to Homoian orthodoxy. This was counterbalanced by Hilderic in $523 \mathrm{CE}$ by a grant of tolerance.

A review of the Carthaginian Council convened under Huneric in $484 \mathrm{CE}$ shows a replay of the $411 \mathrm{CE}$ council between Catholics and Donatists (HP 2.47-3.8, Fournier 2008:113-115; Moorhead 1992:41-66). The implication included conformity to a Constantinian conciliar script by the Vandal rulers. Their conformity to the Roman decorum imitatio imperii appears to have pervaded all spheres of power. The label bestowed upon them as persecutors of Nicene orthodoxy can also be inverted as defenders of the African Homoian faith.

Consequently, there is a great similarity between the deductions of narratives from Optatus and Victor to get a perspective of their respective eras. Both approached their accounts as deduced from persistent conflict or persecution. The works Against the Donatist (Phillips 1917) and History of the Persecution of the African Province (Moorhead 1992) hint towards a polemic stance against those opposed to Nicene or imperial orthodoxy or, rather as they claim, catholic orthodoxy. The compromising feature in these narratives is the authors' involvement and stand in the divide.

\section{An African versus Roman divide}

A fact reiterated by Whelan is that Victor's black and white illustration of Vandal Arianism versus Roman Nicene orthodoxy can be misguiding (Whelan 2018:15). Correspondingly, narratives in this category can be said to have preconditioned the African Christian story. The Donatist resurgence post-conflict, even ideologically, as representation of divergence from Catholicism in North Africa is a worthy case study in this regard. The prevalence of these groups deemed divergent from the institutionalised ideology in respective areas distinguishable in sociocultural and ethnic dynamics could be evidence of their viability and authenticity. This implies that their fallout with the perceived 'orthodox or universal' views can be categorically political.

Without reverting to the two distinct theories where the Donatists were conceived as either nationalistic or strictly theological, there appears to be a case for sociocultural dynamics (Wilhite 2017:219-221). This fact raised by Roldanus (2006) lately resurges in Wilhite (2017) in his volume that derives from an inclination towards an organically defined Ancient African Christianity. An acknowledgement of the self-definitive events in early Christianity brings to view the complex matrix of a religion shaped in socio-ethnic dynamics and politics.

The Jewish-Christian Schism, Hellenism and imperial intervention in the person of Constantine conceived the orthodoxy behind these schisms in the 4th century CE. Correspondingly, it appears that socio-ethnic dynamics would continually remain definitive of certain elements of Christian orthodoxy. The Donatist movement identified with native Africa as a perceivably home advantage in the controversies that ensued because of socio-ethnic features.

Wilhite (2017:220) cites an intrinsic cultural use of the native Punic language in reference to religion and religious rites as one of the reasons. The other reasons include their biblical reference to African-ness as having a prophetic continental destiny, one of spiritual eminence (Augustine City of God 16.21 Schaff 1885c:462; Tertullian On Monogamy 17.2, Schaff 1855a:124). Lastly, their identification with the resistance against Rome was characteristic of the historical tension between Carthage and Rome (Against Donatists 3.3.13, Phillips 1917:133). Despite the ambiguity surrounding the notion of the concept of Carthaginian nationalism as bracketing the Donatist narrative, it appears that such a theory is however feasible.

The observations regarding Donatism bear implications for the Vandal Arian-Nicene orthodoxy divide. This is with regard to the geographical identification of orthodoxy as conditioned by the respective sociocultural and political forces available. 


\section{Episcopal polities in Vandal Africa}

The distinction of Vandal African Christianity consequently implies the use of Vandalic, Punic as belonging to the region. Current researches have however suggested a rather bilingual liturgy (Conant 2012:63).

Whelan's (2018:41) evaluation argues for mutually ethnic and linguistic plurality amongst Homoian and Nicene churches in Vandal Africa. Definitive ecclesiastical polities relate to the patronage of the clergy by the Vandal regime (Whelan 2018:46).

According to some researchers, the Vandal Homoian church was a state apparatus: an extension of the Hasding dynasty's regime (Maier 2005:287-289). This proposition is intrinsically problematic based on the self-definitive trajectory taken by Christianity after Constantine. The assertive tone and role of clerics was an over-arching characteristic of imperial episcopal relations, especially with Constantine's successors. Africa being the cradle of the co-architecture of episcopal authority in the person of Cyprian implies some dysfunctionality with the conclusion that Vandal Homoian bishops were completely royal functionaries.

The notion of a state church in Vandal Africa has been contested (Leppin 2003:238). This perception, 'unhelpfully elides the interests of two quite separate institutions' whilst ignoring significant dynamics in Christian thought 'that found collaboration with secular authority profoundly unsettling' (Whelan 2018:42).

As discussed earlier, the view of Homoian bishops as an extension of the Hasding dynasty is a result of the stereotyped source of Nicene opponents. Primarily, derivations for this thinking were Victor of Vita's History of the Persecution and the Life of Fulgentius (HP 1.43-44, 1.48, Moorhead 1992:18-21); (V. Fulg. 6-7, 21, Eno 1997:16-21, 40-43).

The presented accounts depict the Homoian clerics as to have been entangled with Hasding politics.

Jucundus's involvement with the royal sibling Theoderic and his inflicted prosecution to the flames (HP 2.13, Whelan 2018:42) in Victor's account merits the conclusion of the Homoian clergyman as ('suo...Iucundo presbytero') Jucundus was Theodoric's presbyter. The reality of royal chaplains overshadows the existence of ordinary bishops and priests in Victor of Vita or Fulgentius. A review of the careers of Ursacius of Singidunum and Valens of Mursashow shows their existence beyond ecclesiastical polities (Barnes 1993:6, 22-23, 97-100).

The mandate by Huneric transferring churches and estates from Nicene to Homoian bishops (HP 3.14 Whelan 2018:44) is an echo of the Constantinian imperial policy for Christian infrastructural expansion through acquisition of pagan temples. The implication of the edict being persecution of a particular Christian sect would resonate with how the Donatist issue posed a challenge for the emperor's benefactor policy on who was entitled for patronage. This imperial empowerment was a primary definitive feature of the clerical-political relations. The dynasty was furthering the religious mandate of the church.

The negativity from the Nicene text could also have been a consequence of the urban popularity gained by Homoian clerics as a result of their dispensation of charity, this (charity) being a factor of the endowments of the Vandal kings (Whelan 2018:45). Their quasi-judicial capacity (cf. Whelan 2018:45) coupled with an ecclesiastical political rivalry practice implicating kings resonates with the narrative regarding the late antiquity episcopate. Judicial authority was deemed as a divine endowment in the ideology framed by key African episcopates (Augustine Commentary on Gospel of John, 33; Atkins \& Dodaro 2001:101-107).

The observations regarding the ecclesiastical polities in Vandal Africa argue for a continuation of a well-established Christian order despite the political changes after the decline of western Rome. This serves as an entrenchment of the legitimacy claims of an independent Christian regime in North Africa as a background to Ethiopian Christianity. The Byzantine re-conquest of Africa was unarguably going to be a definitive feature in the respective Christianity. The pertinent question will relate to how this would impact the autonomy and distinctive features of African Christianity as this would have implications on how it would influence its region.

\section{Byzantine Africa}

Byzantine Rome as per its establishment under Constantine appears to have retained a claim upon Christendom. The relationship between Byzantine Rome and Christianity in other domains implies a contact between imperial orthodoxy and its adherents. Despite the emergence and existence of distinctly regional Christianities, the cooperation and intervention of Byzantine emperors imply a perpetuation of Constantinian religious policy.

Byzantine-induced policy in Vandal regions regarding Christianity was evident when the emperor Zeno and the Western empress-regent Placidia requested Huneric the Vandal ruler to grant some autonomy to the Nicene clerics to appoint their own episcopate for Carthage. Eugenius was elected as successor of Deogratias in 481 CE (Wilhite 2017:273).

The Byzantine re-conquest of Africa witnessed the resistance from local people. The reversal of Vandal patronage of Homoian Christianity by Byzantine emperors further affirmed their connection with Nicene orthodoxy; consequently, this was resisted by sections that did not fall under their domain (Wilhite 2017:292, 294). The actions of Byzantine emperors generate a revisionist argument regarding what is termed persecution of Christianity by the Vandals; additionally, the effectiveness of neo-Christendom policy in the African region has extended implications for the emergence or entrenchment 
of an organically African tradition that developed in resistance to foreign imposition. The preceding observations have implications upon the existence of an autonomously or organically African Christian tradition.

\section{Byzantine's neo-religious policy}

The exile of Nicene bishops, the acquisition of Nicene churches and their transfer to Homoian Vandal counterparts were avenged with the re-assumption of Roman power in Africa by Byzantine rulers. These actions were legislated against all who were not part of the Nicene party by the emperor Justinian, whether Jews, Arians or Donatists. This signified a Constantinian policy for the promotion of Christianity by Justinian (Wilhite 2017:293). Although it is a matter of perspective, this depicts the Roman or Byzantine emperor as a persecutor of alternative Christian orthodoxy other than Nicene practice, thereby perpetuating imperial orthodoxy or Christianity. In summary, the neo-Christendom policy in regained Roman, formerly Vandal, Africa was notably:

1. In an attack directed at the Donatist, a prevention of rebaptised persons to serve in the army (militiam) (Body of Civil law: New Law 37.7 trans Wilhite 2017:293).

2. Return of basilicas under Vandal custody to the Nicene Bishopric then under the leadership of Reparatus of Carthage who was to preside over 'the council of all Africa' (Body of Civil law: New Law 37.1 trans Wilhite 2017:293).

3. In an enculturation drive, there was a discontinuity by the Byzantines of opus Africanum architecture, which was a Punic-Carthage expression and through infrastructure this was replaced by an eastern Roman infrastructure (Adam 2005:233).

4. Upon readmission to Nicene beliefs, Vandal clergy were relegated to laity (Burns \& Jensen 2014:195).

5. Lastly, the emperor Justinian re-enacted the modulus for Nicene conciliar orthodoxy, local councils. Notably between 523 and $646 \mathrm{CE}$, records show the convention of the Catholic church (Wilhite 2017:293).

\section{Resurgent resistance}

The matrix for neo-Christendom was not guaranteed despite the re-conquered African territory. The resistance of local groups to Byzantine rule, such as the Mauretanian and the remaining Vandals, was not limited to political spheres alone but to the religious domain too. The resurgent intransigence of certain local clerics in Africa against conciliarism is an example. The 525 CE council of Carthage was poorly attended possibly because of the resistance by local episcopates to this notion of conciliarism (Wilhite 2017:293). The resistance to the synods would be consequent of resistance of the Byzantine emperor being an arbiter of orthodoxy through the Nicene party (Wilhite 2017:295).

The pervading landscape dynamics relating to the dominion of the recaptured African territory posed an enculturation self-definitive challenge in re-institution of the eastern form of Christianity. Despite the notable silence in contemporary documents from the respective era regarding Donatist existence, out of the non-retained territories by Byzantine Rome in Africa the inland and western regions surrounding Carthage and Mauretania showed the possibility of Donatist presence.

The previous theory has certain weak points given the lack of veracity regarding the intrinsic existence of the Donatists. However, as propounded by Wilhite (2017), the prevalence of a religious and cultural resistance in certain regions of North Africa to what was foreign resonated with the preceding Donatist-Catholic conflicts.

A notable feature of future conflict between Byzantine Christianity was how certain elements of African resistance implied a metamorphism of the designation Donatist into ideologising resistance to the Catholic orthodox movement (Augustine Ep 105: Augustine to the Donatist, Atkins \& Dorado 2001:162-173).

\section{The three chapters controversy}

The controversy during 400-500 CE regarding the two natures of Christ, stemming from the condemnation of one Nestorius in $431 \mathrm{CE}$ at the council of Ephesus wrangled the Christian empire (Theodoret Anath, Dialogues, Schaff 1885e:58-59, 371-540). 'Nestorianism' as it became called was composite to a trajectory of ecumenical councils that were Trinitarian such as the Chalcedonian council in $451 \mathrm{CE}$.

The notable issue surrounding this controversy is the prevalence of African voices in dissent with regard to the established view. The emperor Justinian condemned three episcopates that had a connection to Nestorius or had urged tolerance to his views of two natures. These bishops were Theodore of Mopsuestia (350-428 CE), Theodoret of Cyrrhus (c393-460) and Ibas of Edessa (c457 CE) (Wilhite 2017:296). The condemnation CE was however of different categories; while Theodore of Mopsuestia was attacked with regard to his person and opera, Theodoret's writings faced the heretical axe and for Ibas it was but one letter.

The division pitted two names at either end of the controversy: Cyril who refuted the two natures and Nestorius who insisted for a distinction (Theodoret Anathemas of Cyril, Schaff 1885e:58-59). The turmoil embroiling the whole empire ensued primarily as a result of emperor Justinian's affirmation or condemnation of a particular sect. The three chapters (mentioned bishops) had aggregating positions that sought a middle ground; but the inclination of refuting Cyril's view is what implied their association with Nestorius (Theodoret Prologue 7, Schaff 1885e:36-38). These bishops underwent trials and conciliar condemnation - Theodoret tried at the 451 CE Chalcedonian council and Ibas tried in Tyre in 449 CE (Wilhite 2017:296). To escape the heretic label, they had denounced Nestorius despite their not so monophysite or single nature views. 


\section{Politics of Neo-Chalcedonianism}

The very western representative of Catholic orthodoxy, Pope Vigilus, opposed the emperor Justinian's actions in the condemnation of the three bishops. In $548 \mathrm{CE}$, he gave in only to retract given the disapproval of other western bishops (Theodoret Prologue 7, Schaff 1885e:37, 38). A council convened by the emperor, the second council of Constantinople, was unattended by the Pope. The actions of the council of Constantinople are what embroiled Africa.

It has to be noted that the hostility the emperor faced came from both sides: the Cyrilian and the Nestorian. The pope, for example, was not in support of Nestorianism but the actions of a council could not be reversed. If the three chapters had not been deemed Nestorian, they would not have been condemned.

The emperor's actions were ratified through the council by citing how Augustine emphasised actions against heretics even when they were dying (Price 2009). The African clerics were to attack the emperor and the western patriarch, the pope, for his involvement in retraction of synods. It has to be remembered that in Africa the concept of conciliarism was established through Cyprian's emphasis on episcopal authority (Unit Eccl 10-14; Hall 2012:479; Schaff 1885b:744-746). The resistance to ecumenical synods was an entrenchment of local tradition; but regarding the sacredness of councils, the Africans would not accept the edict of even the emperor.

Even the Nicene bishop at Carthage, Reparatus, was in opposition to the emperor; consequently, he was exiled after summons. There was local resistance to the installation of a replacement of the Nicene bishop of Carthage (Markus 1979:144). Wave after wave of African clergymen would raise their voice against the actions of the emperor in what they perceived as a negation of the council to mention some Verecundus of Junca and Facundus of Hermionem.

Notably, Facundus urges the Church to be resistant to the political influence of the emperor. This can be aligned with the African Christian tradition as reflected by Tertullian and Donatus (Markus 1979:144). Faccundus, although resistant to the emperor, refused to be labelled as a Donatist. This would be reflective of the Christian empire of Ethiopia, which, despite taking views regarding the monophysite position contrary to that of Rome, would still cooperate on geopolitical matters with the emperor.

\section{Gregory and intransigent Africa}

In $590 \mathrm{CE}$, Gregory, an aristocrat by training, became the bishop of Rome (Wilhite 2017:301) - for his acumen he amassed the magnus [great] title, enlisting him with the likes of Constantine and Pompeii the general. Yet there was a dilution to the power of the western bishop - the real power in the west as it would appear - as there was no western emperor to talk about.
The African church and its non-compliance posed a challenge to the authority of the Roman See. In his letters, Gregory appears to be engaged immensely with the African church, and notably resurgent Donatists against unum baptisma [one baptism] and unititas [unity] (Cameron 1982:51). This poses a challenge given the earlier establishment regarding the nonexistence of evidence for Donatism during the Vandal and post-Vandal era. Yet the narrative of resistance resonates with the actions of the Donatists in preceding centuries.

According to Wilhite (2017), this also provokes a resurgent revisionist enquiry regarding the nature of African Christianity and its resistance. According to Markus (1994:162, $163)$, ' $[w]$ hat Gregory interpreted as Donatism was nothing more and nothing less than the African Church's traditional sense of autonomy re-asserting itself'. This bears significance as an intonation of the regional influence that would determine the shade of Christianity pervading North Africa.

The incapacitation of the bishop of Rome to curtail or relegate the African bishops also establishes the significance of episcopal polities and how they now were geographically defined. The feature of ecclesiastical polities being a selfdefinitive feature of Christianity implies the emergence of an autonomous structure in Africa. Given the resistance against the emperor in the three chapters controversy, resistance against his less political accomplice in the Western half of the empire only became easier. The incapacity of the pope to act independently of the fellow episcopates is established (Martyn 2004:40).

Conant's position regarding African Christianity was a counter-balance of the resistance against foreign encroachment from the emperor in Rome and the bishop in Constantinople versus its acceptance of certain principles of the empire or pope's authority (Conant 2012:329). For Markus, these issues bring us to a view of an African orthodoxy: the emperor's role in orthodoxy and the independence of the African Church (Markus 1979:146).

These observations are taken as problematic because of some of the assumptions they are based on, such as the ethnicity of the resistance parties as shown by Berbers or Markus's rebuttal of a nationalistic sentiment in African society that would influence Christianity. It is my view that socio-ethnic dynamics were a strong influence in the self-definitive process in this case of African Christianity. The afforementioned socio-ethnic dynamics, spark an enquiry regarding the Christian influence from these regions. This is because the reality regarding socio-ethnic dynamics was prominent in essentially non-Roman areas such as Ethiopia.

\section{The Christian empire of Ethiopia}

In Eastern Africa, chronologically analogous to the emerging imperial-episcopal complex in the Roman empire, the Christian empire of Africa was rising. The interplay of imperial-religious relations between Ethiopia and Byzantine establishes a theory of mutual autonomous significance in 
respective regions. The self-assertive dominion of the Ethiopian emperors as kings over a vast territory including Himyar Arabia (then Judaic in practice) was explicit.

The Ethiopian negus [ruler or emperor] was the king of kings over Axum [Ethiopia], Himyar, DhuRaydan in the Hadramawt and Saba in Yemen (Bowersock 2013:64). The sovereign claims regarding the Arabian Peninsula were however fluid and at times nominal (Bowersock 2013:64). The presence of Sassanian Persians in the region complicated the territorial matrix as this was the dominant power challenging Byzantine expansion (Theodoret Hist. Eccles 3.16, Schaff 1885e:236).

The affiliation of Persians with Jewish Arabs in the region would imply a religious divide and consequently alliances. The preceding factor entailed the geopolitical cooperation between the Byzantine and Ethiopian empires regarding the common Persian enemy. This premised a religious political connection between the two empires (Byzantine and Ethiopia). Given the imperial nature of Byzantine orthodoxy, this inter-imperial correspondence would by extension implicate the Christendom.

The Christian matrix of Ethiopia that derived from its Judaic heritage implies the complexity of this orthodoxy selfdefinition agenda. Whilst given the discussion regarding Byzantine relations with the 'Donatist' African church, the interaction of Ethiopian Christianity with Byzantineestablished orthodoxy would reflect the intricacy of selfdefinitive politics.

\section{Ethiopia and post-Nicene orthodoxy}

The narrative regarding the Christianisation of Ethiopia and its actively Christian emperors is a sketchy record but with substantial backup in the form of tradition (Theodoret Hist. Eccles 1.22, Schaff 1885e:127).

The missionary to the Ethiopian monarch Frumentius, a descendant of Alexandria, is embroiled at the centre of the exhibition of imperial orthodoxy by Byzantine Rome. During the tenure of the post-Nicene upheaval, the anti-Arius party found resonance with Athanasius, a bishop in Alexandria. At the ascension of Constantius II, the centre of influence with the emperor which had gradually drifted from the antiArian party to somewhat middle ground implied Arianism as the new orthodoxy (Rufinus, Hist.Eccles.2.5.14 [Amidon 1997:18-23]; Athanasius. Apol. 29, 31 1892:495, 497-498).

The Byzantine emperor as established earlier required the realignment of the Axumite bishop with current powerorthodoxy dynamics. This was through an examination at the hands of the new Arian patriarch of Alexandria, George. As established earlier, the reciprocation to this action has no evidence. This narrative when placed in the background of the preceding discussion implies the coherent trajectory of African intransigence.
The religious matrix of Ethiopia was complex as already registered; this primarily derived from the Jewish Christian connection in their heritage as found in the KebraNagast. The legend of Queen Makeda or Queen of Sheba and her Solomonic romance and the Solomonic dynasty attests to this fact (Bowersock 2013:82). Additionally, the prevalence of Judaism in Himyar, a territory under Ethiopian rule (in certain eras), implied a confluence of Christianity and Judaism after the imperial conversion from paganism. It is likely that given the nature of monotheistic Judaism, Ethiopian Christianity would be conservative regarding its theology (view of the deity). This would have implications as to which side it would incline in Christological controversy.

The rejection of the Chalcedonian council of $451 \mathrm{CE}$ as dyaphysite could be the result of the Judaic influence upon Ethiopian theology. The KebraNagast would castigate the emperor Marcianus who oversaw the council as a heretic (Bowersock 2013:83). Consequently, the Christianity of Ethiopia would be monophysite as that of Syria and Palestine and divergent from the Byzantine orthodoxy. This poses a new dynamic in the three chapters controversy given the geographical location of Ethiopia.

As an African church conformity to Chalcedon was the norm, yet for reasons unlike those of the emperor Justinian who denounced the council as an imperial political score, the Ethiopians formed their anti-Nestorian party along theological lines. Interestingly, the association with Palestinian and Syriac Christianity resonated with their Judaic-Christian background. Irrespective of the complexity of the relationship between the Christianity of Ethiopia and Byzantine Christianity, what can be established is how ethnopolitical dynamics shaped the Ethiopian orthodoxy. The other notion possibly surrounding the Ethiopian rejection of Chalcedonianism was the council's rejection by Coptic Egypt (Binns 2017:23). Whilst Ethiopia's Abuna system was aggregately derived from the patriarch of Alexandria (Isaac 2013), Ethiopia's regional significance expanded its role within Eastern Christianity. It came to comprise the proEastern Christian propaganda that showed Ethiopia as a defender of Christianity from Islam and superior to Byzantine heresy (Pseudo-Methodius Hendrickx 2012; Penn 2015).

Being Jewish is a matter of both practice and ethnicity; the confluence of Ethiopian territory with Judaism and Christianity and correspondingly their historical transition from Judaismpaganism into Christianity was definitive. The Ethiopian religious outfit would be a stand-alone relative to Byzantine or North African orthodoxy. This however does not complete the picture of the Byzantine and Ethiopian religious cooperation.

\section{Conclusion: Imperial Byzantine and the Kingdom of Ethiopia}

The Constantinian influence was not restricted geographically and chronologically as it would seem. The ability of Constantine to attach himself to the bandwagon of a 
world-capturing religion correspondingly perpetuated his legacy. The impact of the Constantinian era upon Christendom, rather than the interaction between Christianity and politics, was far-reaching. Introspectively, the definitive nature of a religious polity upon Christianity cannot be undermined; additionally, the socio-ethnic dynamics are precursor to the development of Christianity throughout its narrative.

The autonomy and uniqueness of Christianity in Africa and its resistance to imperial imposition have been noted as definitive of African Christianity. The possibility of resistance being nurtured ideologically and ethnically perpetuated in the person of Donatism implied the home advantage or rather nationalism. These considerations build a composite picture for an organic orthodoxy. Whilst there has been intrinsic emphasis upon the divergent nature of African Christianity as the background to Ethiopian orthodoxy, the balance between political and religious divergence is noteworthy.

The autonomy and independence of North African Christianity as established cannot be swept underneath a nationalistic sentiment in resistance to the imperial orthodoxy establishment. African bishops could be anti-Byzantine orthodox yet not Donatists. This deduces the in-equitability of theological or religious divergence and political divergence. The Ethiopian narrative conforms to this theory.

The cooperation between Ethiopia and Byzantine Rome in support of persecuted Christians in Jewish Arabian Najran is a notable account. The Byzantine emperor Justin and Ethiopian negus Kaleb invaded Himyar in 525 (Bowersock 2013:106). This conceived a geopolitical alliance between the two kingdoms: expansion of Ethiopian territory and for the Byzantines a neutralisation of the Persian power (Dewing 1914-1928:1:178-195; Procopius Wars I.19-20). The conquest was a bid in the re-entrenchment of Christian presence in the Arabian Peninsula; undoubtedly, this was a continuation of imperially backed religion and inevitably this implied an Ethiopian client of Christianity in Himyar.

Lastly, an explicit exhibit of conformity to Rome was a form of imitatio imperii [imperial imitation] by certain Ethiopian rulers. One could say an Ethiopian Constantine. The archaeological evidence implies his name was MHDYS and his rule was in the early 450 CE (Bowersock 2013:76). This emperor reiterated the Constantinian utterances upon his coinage like Constantine's in hoc signo vinces 'that is in this cross you will MHDYS claimed also to 'temawe' [Ethiopic] he will conquer by the 'masqal' [Ethiopic] cross (Bowersock 2010:218-219). This established the fact that theological divergence was not a rejection of the influence of Rome intrinsically (Cameron \& Hall 1999:38-39).

The major deduction of accepting an autonomously independent Christianity that was not subservient to Byzantine, but one that interacted at a level of equality, enhances the African Christianity narrative. The Ethiopian Christian empire, given its autonomous background, implies the development and expansion of a unique Christian outfit. Shaped by socio-ethnic dynamics beyond Roman influence, an Ethiopian orthodox would be organic to Ethiopia and its region.

\section{Acknowledgements}

Prof. Erna Oliver's guidance is acknowledged. The authors thank the University of South Africa for the research support.

\section{Competing interests}

The authors have declared that no competing interest exist.

\section{Author(s) contributions}

Both authors contributed equally to this work. R.R. is the main author and Prof. E. Oliver is the co-author and provided guidance and helped in consolidation process.

\section{Ethical consideration}

This article followed all ethical standards for a research without direct contact with human or animal subjects.

\section{Funding information}

This research received no specific grant from any funding agency in the public, commercial, or not-for-profit sectors.

\section{Data availability statement}

Data sharing is not applicable to this article as no new data were created or analysed in this study.

\section{Disclaimer}

The views and opinions expressed in this article are those of the authors and do not necessarily reflect the official policy or position of any affiliated agency of the authors.

\section{References}

Adam, J., 2005, Roman building: Material and techniques, Routledge, London.

Alexander, D.C. \& Smither, E.L., 2015, 'Bauer's forgotten region: North African Christianity', in P.A. Hartog (ed.), Orthodoxy and heresy in early Christian contexts: Reconsidering the Bauer thesis, pp. 166-192, Pickwick Publications, Eugene, OR.

Amidon, P.R., 1997, The Church history of Rufinus of Aquileia, books 10 \& 11, Oxford University Press, New York.

Amidon, P.R., 2007, Philostorgius: Church history, Society of Biblical Lit, Atlanta, GA.

Atkins, E.M. \& Dorado, R.J. (eds.), 2001, Augustine political writings, Cambridge University Press, New York.

Barnes, T.D., 1993, Athanasius and Constantius: Theology and politics in the Constantinian empire, Harvard University Press, Cambridge, MA.

Barnes, T.D., 2011, Constantine. Dynasty, religion and power in the Late Roman empire, Wiley-Blackwell, Chichester.

Binns, J., 2017, The orthodox church of Ethiopia: A history account, I.B. Tauris, London.

Bowersock, G.W., 2010, Helena's Bridle, Ethiopian Christianity, and Syriac Apocalyptic, vol. 45, pp. 211-220, Studia Patristica, Leuven.

Bowersock, G.W., 2013, The throne of Adulis: Red Sea Wars on the Eve of Islam, Oxford University Press, New York.

Burns, J.P. \& Jensen R.M., 2014, Christianity in Roman Africa: The development of its practises and beliefs, Eerdmans, Grand Rapids, MI. 
Cameron, A., 1982, 'Byzantine Africa: The literary evidence', in J.H. Humphrey (ed.) Excavations at Carthage, vol. 7, pp. 29-62, University of Michigan, Ann Arbor, MI.

Cameron, A. \& Hall, S.G., 1999, 'Eusebius: Life of Constantine I', Clarendon ancient history series, University Press Inc, New York.

Conant, J., 2012, Staying Roman: Conquest and identity in Africa and the Mediterranean, 439-700, Cambridge University Press, Cambridge.

Dewing, H.B. (ed. \& trans.), 1914-1928, Procopius: History of the wars, Heinemann (Loeb Classical Library), London.

Eno, R.B. (trans.), 1997, Selected works (the fathers of the Church), Fulgentius, Saint Fulgentius Bishop of Ruspa, CUA Press, Washington, DC.

Fournier, E., 2008, 'Victor of Vita and the Vandal persecution: Interpreting exile in Late Antiquity', PhD dissertation, University of California, Santa Barbara, CA

Fournier, E., 2013, Victor of Vita and the Conference of 484: A Pastiche of 411? vol. 62, pp. 395-408, StudiaPatrisca, Leuven.

Frend, W.H.C., 2012, 'Persecutions: Genesis and legacy', in M.M. Mitchell \& F.M. Young (eds.), The Cambridge history of Christianity: Origins to Constantine, pp. 503-523, Cambridge University Press, New York.

Gray, P.T.R., 2005, 'The legacy of Chalcedon', in M. Maas (ed.), The Cambridge companion to the age of Justinian, pp. 215-238, Cambridge University Press, New York.

Hall, S.G., 2012, 'Ecclesiology in the wake of persecution', in M.M. Mitchell \& F.M. Young (eds.), The Cambridge history of Christianity: Origins to Constantine, pp. 470-483, Cambridge University Press, New York.

Hendrickx, B., 2012, 'Political theory and ideology in the KebraNagast: Old Testament Judaism, Roman-Byzantine Politics and Ethiopian Orthodoxy', Journal of Early Christian History 2(2), 22-35. https://doi.org/10.1080/2222582X.2012.11877263

Isaac, E., 2013, The Ethiopian Orthodox Tawahido Church, The Red Sea Press, Trenton, NJ.

Leithart, P.J., 2010, Defending Constantine: The twilight of an empire and the dawn of Christendom, InterVarsity Press, Downers Grove, IL.

Leppin, H., 2003, Theodosius der Grosse, Primus Verlag, Darmstadt.

Maier, G., 2005, Amtstrager und Herrscher in der Romania Gothica: Vergleichende Untersuchungen zu den Institutionen der ostgermanischen Volkerwanderungsreiche, Historia Einzelschriften 181, |Franz Steiner Verlag, Stuttgart.

Markus, R.A., 1979, 'Markus, reflections on religious dissent in North Africa in the Byzantine period', in D. Baker (ed.), Schism, heresy and religious protest, Studies in Church History 16, Cambridge University Press, Cambridge, Reprinted essay VII in From Augustine to Gregory the Great: History and Christianity in Late Antiquity, Variorum, London.

Markus, R.A., 1994, 'The problem of Donatist in the sixth century', in École française de Rome, Gregorio Magno e ilsuo tempo, Reprinted in Sacred and Saecular: Studies on Augustine and Latin Christianity, Variorum, Aldershot.
Martyn, J.R.C., 2004, The letters of Gregory the Great, 3 vols., Medieval Sources in Translation 40, Pontifical Institute of Medieval Studies, Toronto.

Moorhead, J. (trans.), 1992, Victor of Vita: History of the vandal persecution, vol. 11, Liverpool University Press translated texts for Historians: Liverpool University Press, Liverpool.

Penn, M., 2015, When Christians first met Muslims: A sourcebook of the earliest Syriac writings on Islam, University of California Press, Berkeley, CA.

Phillips, V., 1917, The work of St. Optatus against the Donatists, Oxford University Press, New York.

Phillipson, D.W., 2012, Foundations of an African civilisation: Aksum \& the Northern Horn $1000 B C-A D$ 1300, James Currey, New York.

Price, R., 2009, The acts of the Council of Constantinople of 553, 2 vols., Liverpool University Press, Liverpool.

Rapp, C., 2005, Holy bishops in Late Antiquity, University of California Press, Berkeley, CA.

Roldanus, J., 2006, The church in the age of Constantine: The theological challenges, Routledge, London.

Schaff, P. (ed.), 1885a, Ante-Nicene fathers. Vol. 4: The fathers of the third century: Tertullian part IV; Minucius Felix; Commodian; Origen, Christian Classics Ethereal Library, Grand Rapids, MI.

Schaff, P. (ed.), 1885b, Ante-Nicene fathers. Vol. 5: The fathers of the third century: Hippolytus; Cyprian; Caius; Novatian; appendix, Christian Classics Ethereal Library, Grand Rapids, MI.

Schaff, P. (ed.), 1885c, Nicene and post-Nicene fathers. Series 1. Vol. 2: St. Augustine's City of God and Christian doctrine, Christian Classics Ethereal Library, Grand Rapids, MI.

Schaff, P. (ed.), 1885d, Nicene and post-Nicene fathers. Series 2 vol. 1: Eusebius Pamphilius: Church history, life of Constantine, oration in praise of Constantine, Christian Classics Ethereal Library, Grand Rapids, MI.

Schaff, P. (ed.), 1885e, Nicene and post-Nicene fathers. Series 2. Vol. 3: Theodoret Jerome, Gennadius, \& Rufinus: Historical writings, Christian Classics Ethereal Library, Grand Rapids, MI.

Schaff, P. (ed.), 1892, Nicene and post-Nicene fathers. Series 2 vol. 4: Athanasius Select works and letters, Ecclesiastical History, Grand Rapids, MI.

Van Dam, R., 2012, 'Bishops and society', in A. Casiday \& F.W. Norris (eds.), The Cambridge history of Christianity: Constantine to c. 600, pp. 343-367, Cambridge University Press, New York.

Whelan, R., 2018, Being Christian in Vandal Africa: The politics of orthodoxy in the post-imperial West, University of California Press, Oakland, CA.

Wilhite, D.E., 2017, Ancient African Christianity: An introduction to a unique context and tradition, Routledge, New York. 